\title{
To Analyze the Modifier Effect of NOS3 Gene in Hypertensive Patients of ADPKD
}

\author{
Shiva Nagendra Reddy Annapareddy ${ }^{1}$, Pratap Duggirala ${ }^{2}$ \\ ${ }^{1}$ Assistant Professor, Department of Nephrology, NRI Medical College \& Hospital, Chinakakani, Guntur, Andhra Pradesh, India, ${ }^{2}$ Assistant Professor, \\ Department of Plastic Surgery, NRI Medical College \& Hospital, Chinakakani, Guntur, Andhra Pradesh, India.
}

\section{Abstract}

Background: Nitric oxide is important for the functional integrity of the vascular endothelium and is produced in endothelial cells by the enzyme endothelial nitric oxide synthase (eNOS). Hypertension has a strong genetic component, and the NOS3 gene, which encodes eNOS, represents an interesting candidate for contribution to the phenotype. The most clinically relevant polymorphisms in the NOS3 gene are a variable number tandem repeat (VNTR) in intron 4, and rs2070744 (T-786C) in the promoter region. Subjects and Methods: This study aims to investigate the association between these three polymorphisms in the NOS3 gene and modifier effect on age, progression of disease and hypertension in patients of ADPKD. Results: The present study carryout in the ADPKD patients admitted in NRI Medical College \& Hospital. Univariate and multivariate logistic regression analyses were performed to assess the effect of genotypes and hypertension on the progress of chronic kidney disease (CKD). A stratified analysis was also performed to assess the evidence of the modification of hypertension-CKD relationship among VNTR genotypes. Conclusion: The results of this study indicated that the polymorphism in NOS3 may be a genetic susceptibility factor for hypertension in the Indian population.

Keywords: VNTR genotypes, NOS3 gene, ADPKD, Hypertension.

Corresponding Author: Dr. Pratap Duggirala, Assistant Professor, Department of Plastic Surgery, NRI Medical College \& Hospital, Chinakakani, Guntur, Andhra Pradesh, India.

Received: November 2019

Accepted: December 2019

\section{Introduction}

Polycystic kidney disease (PKD) is a multisystem disorder characterized by the formation of cysts within the kidneys. PKD is mainly caused by the unfolding of its immunoglobulin-like PKD domains. There are two major forms of PKD; autosomal dominant (ADPKD) that caused by mutations of PKD1 and PKD2 $2^{[1]}$ and autosomal recessive (ARPKD) caused by mutations in PKHD1 gene. ${ }^{[2,3]}$ Although, cellular changes and mechanisms involved in initial stages of cyst formation might differ between ADPKD and ARPKD, both are important causes of kidney failure, morbidity and mortality in children and adults of all racial groups worldwide. ${ }^{[4]}$ Further, it is clear that the disease progression in the ADPKD and ARPKD involves almost similar pathogenetic mechanisms. ${ }^{[5,6]}$ Hypertension is an important factor in the progression of kidney failure ADPKD patients, $60 \%$ of ADPKD patients exhibit high blood pressure even before the impairment of kidney function. ${ }^{[7]}$ The prevalence of Hypertension continues to rise despite recent advances in diagnosis and treatment. Approximately $40 \%$ of the global adult population aged 25 and above suffer from hypertension. ${ }^{[8]}$

Another argument for modifier genes influencing renal disease progression in ADPKD is provided by the excess variability in the age at ESRD observed among siblings or dizygotic twin's vs genetically identical monozygotic twins.

\section{Modifier effect of ENOS in ADPKD}

The effect of ENOS on renal disease progression in ADPKD has been assessed recently in a large series of unrelated patients from a restricted geographic area. ${ }^{[9]}$ The frequent Glu298Asp (E/D298) polymorphism of exon 7 of ENOS was associated with a significant, 5 year lower age at ESRD in the whole group of ADPKD males, as well as a lower renal survival (Kaplan-Meier analysis) in males from PKD1linked families. In contrast, no effect was found in females with ADPKD. The more critical influence of ENOS in ADPKD males may be explained by the fact that oestrogens stimulate eNOS expression and the release of $\mathrm{NO}$ in endothelial cells. ${ }^{[10]}$

A molecular basis for the effect of the Glu298Asp polymorphism was provided by the demonstration of decreased enzymatic activity and modified expression of eNOS in renal arteries from patients harbouring the Asp allele. ${ }^{[9]}$ The functionality of this polymorphism has been confirmed independently in vitro. ${ }^{[11]}$ The mechanism by which this conservative amino acid substitution leads to degradation and decreased activity of eNOS remains to be elucidated. The Glu298 of eNOS is conserved among species, and located within the oxygenase domain of 
eNOS. $^{[12]}$ An increased degradation of the Asp298 eNOS may yield a cleaved protein that could contribute to endothelial dysfunction. ${ }^{[13]}$ Alternatively, the Glu298Asp polymorphism may influence the complex post-translational regulation of eNOS. ${ }^{[14]}$ Thus, lower enzymatic activity and/or partial cleavage of eNOS could be responsible for increased endothelial dysfunction, and possibly increased systemic blood pressure and/or alteration of intra-renal microcirculation, in ADPKD patients harbouring the Asp298 allele.

Finally, insights derived from genetic modifiers may lead to therapeutic opportunities. From the data summarized above, a logical approach would be to address specifically the endothelial dysfunction in ADPKD. Nitrates come first to mind, but their systemic use is hampered by tolerance, activation of the sympathetic nervous system and production of superoxide and endothelin. ${ }^{[15]}$ Similarly, the effect of other types of NO donors may be limited by the redox status of the tissue and the potential formation of peroxynitrite. These limitations may be resolved by using drugs that stimulate eNOS expression in endothelial cells, such as statins or ACE inhibitors. ${ }^{[16]}$ In any case, the possibility of pharmacomodulation by the ENOS genotype should be kept in mind.

\section{Hypertension in Autosomal Dominant Polycystic Kidney Disease}

Hypertension is common in ADPKD and is diagnosed early, at a mean age of 29 years. Several mechanisms play a role in the development of hypertension in ADPKD, including hyperactivity of the renin-angiotensin- aldosterone system (RAAS), activation of the sympathetic nervous system and abnormalities of the endothelium.

Hypertension is responsible for the diagnosis of ADPKD in approximately $30 \%$ of patients. Hypertension is a common and early manifestation of ADPKD and occurs in more than $60 \%$ of affected individuals before decline or any substantial reduction in glomerular filtration rate (GFR) has been observed (GFR $>75 \mathrm{ml} / \mathrm{minute} / 1.73 \mathrm{~m} 2 .^{[17]}$

The observation of the high incidence of hypertension in ADPKD patients was first noted in the early 20th century. Studies from 1916, 1931, and 1949 reported an incidence of hypertension of 72,75 , and $73 \%$, respectively, but did not account for the presence of renal insufficiency. ${ }^{[18]}$

Schact et al. reported a much lower incidence of hypertension in age- and gender-matched patients with another non-glomerular renal disease characterized by tubulo-interstitial abnormalities and low-grade proteinuria compared with patients with ADPKD (chronic pyelonephritis $26 \%$ versus ADPKD 73\%).

In chronic kidney disease (CKD), hypertension is in large part due to renal dysfunction and its associated increased sodium retention, as well as the underlying renal disorder. Thus, ADPKD patients are unique where hypertension appears early and independently of renal dysfunction. ${ }^{(19)}$

Additional knowledge of NOS3 gene polymorphisms and their role in hypertension will improve understanding of hypertension, its common predisposing factors, and potential treatment options. The potential contribution of NOS3polymorphisms to the development of hypertension in
Indian population has received no attention to date, and no previous studies have addressed this subject. The objective of the present study is to identify the modifier effect of NOS3 gene with hypertensive patients of ADPKD.

\section{Subjects and Methods}

\section{Subjects}

Patients visiting Department of Nephrology, NRI Medical College \& Hospital, Guntur, Andhra Pradesh during from June 2017-June 2019 for treatment with the complications of cysts in the kidney, will be the main source of the samples in the present study.

The following inclusion criteria will be used in the present study

i. Presence of at least two renal cysts in any one of the kidney, if the individual is aged less than $30 \mathrm{yrs}$.

ii. Presence of at least two renal cysts in each kidney if the individual is aged between 30-60 yrs

iii. Presence of at least four renal cysts in each kidney if the individual aged greater than 60 yrs.

iv. Abdominal ultrasonography will be conducted on each subject

v. Biochemical studies such as serum urea, creatinine and uric acid will be estimated

vi. Urine microscopy and a renal ultrasound also will be performed.

vii. Urine studies for fractional extraction of sodium, fractional excretion of uric acid, and protein/ creatinine ratio will be performed for twenty-four hour basis.

viii. Following their clinical assessments, the blood samples from 50 unrelated subjects with the history of hereditary renal cysts were collected. 90 age and sex matched controls were also be recruited from the same geographical location. Patients with other end stage renal disorders were excluded from the study. Written informed consent was collected from the study participants before collecting the blood samples. DNA from the above samples will be isolated using phenol and chloroform method.

\section{DNA sample preparation}

Venous blood $(5 \mathrm{~mL})$ was drawn from each subject. DNA extraction and genotyping were performed at the Institute. DNA extraction was performed using a Qiagen Gentra Puregene Blood Kit (Qiagen, Germany).

\section{Genotyping}

DNA, extracted from blood samples of the 53 ADPKD and 94 control subjects, was genotyped for intron 4 VNTR of endothelial nitric oxide synthase gene ( NOS3 ) using the forward 5'- AGGCCCTATGGTAGTGCCTTT- 3'and the reverse 5'- TCTCTTAGTGCTGTGGTCAC-3' that flank the region of the $27 \mathrm{bp}$ repeat in intron 4 of eNOS gene.

Materials Required For Polymerase Chain Reaction $\underline{(\text { PCR) }}$ 
All materials required for PCR except high molecular weight

DNA were commercially obtained.

- PCR buffer

- dNTPs

- Taq Polymerase

- Milli Q water

- Primers (Forward and reverse) Primer for NOS3-VNTR

\begin{tabular}{|c|c|c|}
\hline \multirow{2}{*}{$\begin{array}{l}27 \text { bp } \\
\text { intron } 4 \\
\text { VNTR }\end{array}$} & Forward primer & $5^{\prime \prime}$ - AGGCCCTATGGTAGTGCCTTT- $3^{\prime}$ \\
\hline & Reverse Primer & 5'- TCTCTTAGTGCTGTGGTCAC-3' \\
\hline
\end{tabular}

The specificity of the primers was also checked by using the electronic PCR.

\begin{tabular}{|l|l|l|}
\hline PCR Program for NOS3-VNTR: \\
\hline STEPS & TEMPERATURE & TIME \\
\hline Initial Denaturation & $95^{\circ} \mathrm{C}$ & $5 \mathrm{~min}$ \\
\hline Denaturation & $95^{\circ} \mathrm{C}$ & $1 \mathrm{~min}$ \\
\hline Annealing & $60^{\circ} \mathrm{C}$ & $1 \mathrm{~min}$ \\
\hline Extension & $72^{0} \mathrm{C}$ & $1 \mathrm{~min}$ \\
\hline Final Extension & $72^{\circ} \mathrm{C}$ & $7 \mathrm{~min}$ \\
\hline
\end{tabular}

PCR products were resolved and then visualized under UV light.

The PCR products were run on $2 \%$ agarose gel electrophoresis, and the fragments separated were visualized by ethidium bromide staining under UV trans-illumination. PCR analysis of genomic DNA generated fragments of 393 bps corresponding to $4 \mathrm{a} / \mathrm{a}$ homozygotes, $420 \mathrm{bps}$ to $4 \mathrm{~b} / \mathrm{b}$ homozygotes and 393 and $420 \mathrm{bp}$ hetrozygote.

\section{Statistical analysis}

\section{HWSIM Software's}

To indicate statistical significance, $\mathrm{p}$ values, were considered at 0.05 level. Distribution of biochemical variables between cases and controls was assessed using t-Test among genotypes using ANOVA. The association was tested in three different genetic models. All the analysis was done using the SPSS software.

\section{Results}

Table 3: Distribution of different biochemical variables among different NOS3 Genotypes.

\begin{tabular}{|l|l|l|l|l|}
\hline & Wild & Het & Deletion & $\begin{array}{l}\mathrm{P} \\
\text { value }\end{array}$ \\
\hline $\begin{array}{l}\text { Age at renal } \\
\text { failure (Yrs) }\end{array}$ & $47.10 \pm 11.38$ & $48.10 \pm 13.24$ & $\begin{array}{l}44.20 \pm 10.9 \\
1\end{array}$ & 0.762 \\
\hline $\begin{array}{l}\text { Blood Urea } \\
\text { Nitrogen } \\
(\mathrm{mg} / \mathrm{dl})\end{array}$ & $48.67 \pm 25.65$ & $47.52 \pm 17.79$ & $\begin{array}{l}40.17 \pm 13.1 \\
6\end{array}$ & 0.434 \\
\hline $\begin{array}{l}\text { Creatine } \\
(\mathrm{mg} / \mathrm{dl})\end{array}$ & $7.20 \pm 4.02$ & $7.48 \pm 2.63$ & $7.27 \pm 3.75$ & 0.163 \\
\hline $\begin{array}{l}\text { Sodium } \\
(\mathrm{mg} / \mathrm{dl})\end{array}$ & $136.48 \pm 11.72$ & $136.48 \pm 11.39$ & $140 \pm 6.29$ & 0.757 \\
\hline $\begin{array}{l}\text { Potassium } \\
(\mathrm{mg} / \mathrm{dl})\end{array}$ & $4.81 \pm 0.999$ & $4.85 \pm 0.95$ & $4.28 \pm 0.89$ & 0.219 \\
\hline $\begin{array}{l}\text { Chloride } \\
(\mathrm{mg} / \mathrm{dl})\end{array}$ & $97.18 \pm 7.86$ & $99.43 \pm 8.31$ & $94.50 \pm 8.89$ & 0.326 \\
\hline
\end{tabular}

\begin{tabular}{|l|l|l|l|l|}
\hline $\begin{array}{l}\text { Bicarbonates } \\
(\mathrm{mg} / \mathrm{dl})\end{array}$ & $20.42 \pm 4.84$ & $20.95 \pm 4.22$ & $23.5 \pm 2.58$ & 0.274 \\
\hline $\begin{array}{l}\text { Calcium } \\
(\mathrm{mg} / \mathrm{dl})\end{array}$ & $7.83 \pm 0.874$ & $7.70 \pm 0.89$ & $7.70 \pm 0.89$ & 0.842 \\
\hline $\begin{array}{l}\text { Glomerular } \\
\text { filtration } \\
\text { rate }(\mathrm{ml} / \mathrm{hr})\end{array}$ & $16.68 \pm 20.51$ & $9.10 \pm 5.34$ & $11.85 \pm 8.29$ & 0.016 \\
\hline
\end{tabular}

ADPKD can lead to ESRD most commonly in middle age or later in life. In the present study the age at renal failure is not significantly associated with NOS3 genotypes of ADPKD [Table 5].

Table 4: Distribution of CKD stage among different genotypes of ADPKD

\begin{tabular}{|l|l|l|l|}
\hline CKD Stage & Deletion & Het & Wild \\
\hline Satge 1 & 0 & 0 & 2 \\
\hline Stage 2 & 0 & 0 & 5 \\
\hline Stage 3 & 0 & 0 & 8 \\
\hline Stage 4 & 1 & 5 & 9 \\
\hline Stage 5 & 1 & 5 & 17 \\
\hline Chi-square( 8 d.f) & \multicolumn{2}{|c|}{$\mathrm{P}=0.523$} \\
\hline
\end{tabular}

The ADPKD gets worse slowly; eventually resulting in endstage kidney failure, the distribution of VNTR genotypes in different stages of CKD in ADPKD patients was not significant in the present study [Table 4].

Table 5: Changes in the age at renal failure among different genotypes of ADPKD

\begin{tabular}{|l|l|}
\hline Genotype (n) & Age at renal failure \\
\hline Deletion (1) & 51.00 \\
\hline Het (09) & $51.10+10.45$ \\
\hline Wild (30) & $44.95+9.237$ \\
\hline ANOVA (2 d.f) & $\mathrm{p}=0.196$ \\
\hline
\end{tabular}

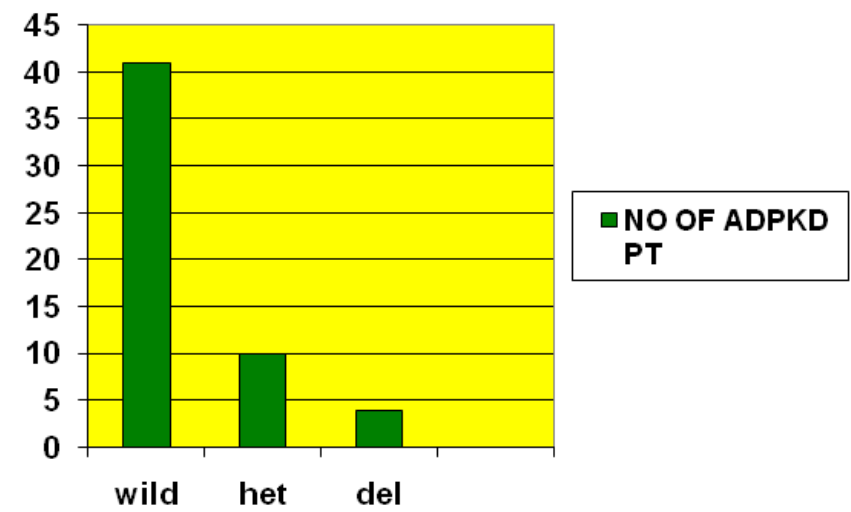

Figure1: Distribution of NOS3 Gene VNTR in control and ADPKD.

Figure 2 depicts the distribution of patients with htn in our study with respect tive polymorphism.

\section{Discussion}

The univariate analysis revealed that the NOS3 VNTR, age and hypertension contributed to the advancement of CKD. After controlling other variables in multivariate analysis, only VNTR genotypes and age were found to increase the risk of CKD advancement in ADPKD. Stratified analysis 
further showed that the NOS3 VNTR was an effect modifier of the relationship between hypertension and CKD advancement among the ADPKD patients. The results were also consistent with the existing reports in this regard. The first study linking this VNTR and hypertension was published by Miyamoto and co-workers. ${ }^{[20]}$ Though these findings were not substantiated in the Australian population, ${ }^{[21]}$ a positive nitrate levels and blood pressure in normotensive African Americans. ${ }^{[22]}$ Further, the a/a genotype of the NOS3 VNTR was shown to significantly increase the risk of developing hypertension in Indian men. ${ }^{[23]}$ Following the conflicting results generated from these association studies, Intron 4 VNTR and haplotype analysis of several other SNPs of NOS3 showed significant association with daytime systolic blood pressure. ${ }^{[24]}$ In the present study $4 \mathrm{a}$ allele was significantly associated with CKD advancement in ADPKD. Higher incidence of 4a allele was observed among Czech patients with end-stage renal disease (ESRD) caused by ADPKD. ${ }^{[25]}$ On the contrary, NOS3 VNTR polymorphism showed no effect on the age at ESRD in unrelated ADPKD patients from Belgium and the north of France (26). Several studies have demonstrated that a decrease of NO synthesis and release may be important in the progression of renal disease. ${ }^{[27]}$

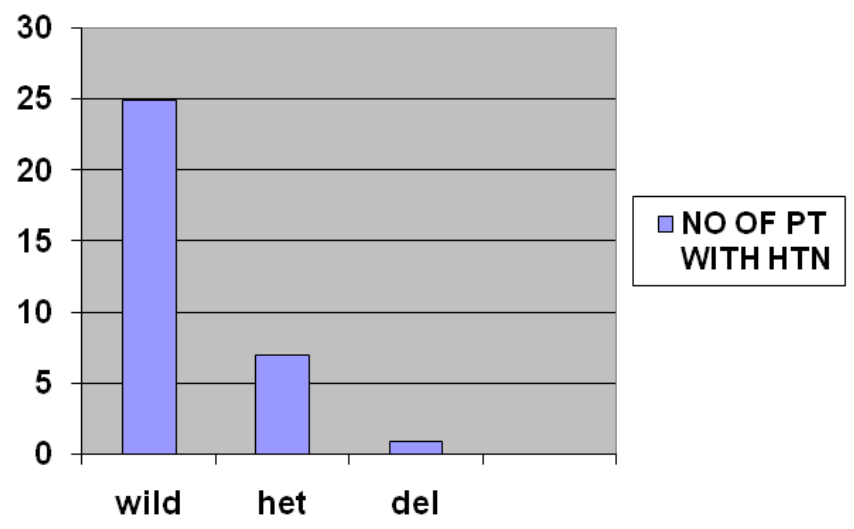

Figure 2: Number of Patient with Hypertension.

This study has number of limitations that are worth mentioning. The small samples size with potential lack of power to the study is a limitation. Furthermore, cases and controls were significantly different in their age, gender, BMI and smoking status. However, statistical analyses showed that none of these variables had an effect on any of the genotypes distribution.

There was also weaker linkage between (rs1799983 and rs2070744), and (rs2070744 and the VNTR). It is unlikely that the VNTR itself has a functional role, as it is in an intronic region. However, it has been suggested to act as a marker for other functional variants elsewhere in the gene. Nakayama et al. first reported that the VNTR is in linkage disequilibrium with rs2070744; hence, the effect of VNTR on NOS3 mRNA expression, eNOS protein concentration, and enzyme activity is likely to be mediated by the differences in transcriptional efficiency associated with the rs2070744 polymorphism. ${ }^{[28-31]}$ The degree of linkage disequilibrium between the three polymorphisms may help in understanding of the evolutionary divergence of the NOS3 gene.

\section{Conclusion}

In conclusion, in this study we demonstrate that the polymorphism in the NOS3 gene promoters associated with hypertension in the Indian population. We identified the significant modifier effect of NOS3 27-bp VNTR and CKD progression in hypertensive ADPKD patients. However, more focused research in this regard is required to further validate our findings. Further studies with larger sample sizes and family-based analyses are required to confirm this association.

\section{Acknowledgement}

The author thankful to Department of Nephrology, NRI Medical College \& Hospital, Guntur, Andhra Pradesh, India for providing all the facilities to carry out this research work.

\section{References}

1. Hateboer N, v Dijk MA, Bogdanova N, Coto E, Saggar-Malik AK, San Millan JL, et al. Comparison of phenotypes of polycystic kidney disease types 1 and 2. European PKD1-PKD2 Study Group. Lancet. 1999;353:103-7.

2. Bergmann C, Kupper F, Schmitt CP, Vester U, Neuhaus TJ, Senderek $\mathrm{J}$, et al. Multi-exon deletions of the PKHD1 gene cause autosomal recessive polycystic kidney disease (ARPKD). J Med Genet. 2005; 42:e63.

3. Sharp AM, Messiaen LM, Page G, Antignac C, Gubler MC, Onuchic $\mathrm{LF}$, et al. Comprehensive genomic analysis of PKHD1 mutations in ARPKD cohorts. J Med Genet. 2005;42:336-49.

4. Gabow PA. Autosomal dominant polycystic kidney disease. Am J Kidney Dis. 1993;22:511-2.

5. Chapin HC, Caplan MJ. The cell biology of polycystic kidney disease. J Cell Biol. 2010;191:701-10.

6. Terryn S, Ho A, Beauwens R, Devuyst O. Fluid transport and cystogenesis in autosomal dominant polycystic kidney disease. Biochim Biophys Acta. 2011;1812:1314-21.

7. Gabow PA, Duley I, Johnson AM. Clinical profiles of gross hematuria in autosomal dominant polycystic kidney disease. Am J Kidney Dis. 1992;20:140-3.

8. World Health Organization. Global status report on non communicable diseases 2010. Geneva: World Health Organization; 2011.

9. Persu A, Stoenoiu MS, Messiaen T et al. Modifier effect ofENOS in autosomal dominant polycystic kidney disease. Hum Mol Genet 2002; 11: 229-241

10. Mendelsohn ME, Karas RH. The protective effects of estrogenon the cardiovascular system. N Engl J Med 1999; 340: 1801-1811.

11. Noiri E, Satoh H, Taguchi J et al. Association of eNOSGlu298Asp polymorphism with end-stage renal disease.Hypertension 2002; 40: 535-540

12. Fischmann TO, Hruza A, Niu XD et al. Structuralcharacterization of nitric oxide synthase isoforms revealsstriking active-site conservation. Nat Struct Biol 1999; 6: 233-242

13. Tesauro M, Thompson WC, Rogliani P, Qi L, Chaudhary PP,Moss J. Intracellular processing of endothelial nitric oxidesynthase isoforms associated with differences in severity ofcardiopulmonary diseases: cleavage of proteins with aspartate vs. glutamate at position 298. Proc Natl Acad Sci USA 2000;97: 2832-2835

14. Fairchild TA, Fulton D, Fontana JT, Gratton JP, McCabe TJ,Sessa WC. Acidic hydrolysis as a mechanism for the cleavageof the Glu(298)! Asp variant of human endothelial nitric-oxide synthase. J Biol Chem 2001; 276: 26674-26679.

15. Luscher TF, Noll G. Is it all in the genes...? Nitric oxide synthase and coronary vasospasm. Circulation 1999; 99: 2855-2857. 
16. Ruschitzka F, Corti R, Noll G, Luscher TF. A rationale fortreatment of endothelial dysfunction in hypertension.J Hypertens 1999; 17: S25-S35.

17. Chapman AB, et al., Adv Chronic Kidney Dis, 2010;17:153-63.

18. Ecder T, et al., J Am Soc Nephrol, 2001;12:194-200.

19. Schrier RW, et al., Kidney Int, 2003;64:1792-9

20. Miyamoto Y, Saito Y, Kajiyama N, Yoshimura M, Shimasaki Y, Nakayama $M$, et al. Endothelial nitric oxide synthase gene is positively associated with essential hypertension. Hypertension 1998;32(1):3-8.

21. Benjafield AV, Morris BJ. Association analyses of endothelial nitric oxide synthase gene polymorphisms in essential hypertension. Am J Hypertens 2000;13(9):994-8.

22. Li R, Lyn D, Lapu-Bula R, Oduwole A, Igho-Pemu P, Lankford B, et al. Relation of endothelial nitric oxide synthase gene to plasma nitric oxide level, endothelial function, and blood pressure in African Americans. Am J Hypertens 2004;17(7):560-7.

23. Patkar S, Charita BH, Ramesh C, Padma T. High risk of essential hypertension in males with intron 4 VNTR polymorphism of eNOS gene. Indian J Hum Genet 2009;15(2):49-53.

24. Persu A, Vinck WJ, El Khattabi O, Janssen RG, Paulussen AD, Devuyst $\mathrm{O}$, et al. Influence of the endothelial nitric oxide synthase gene on conventional and ambulatory blood pressure: sib-pair analysis and haplotype study. J Hypertens 2005;23(4):759-65.

25. Merta M, Reiterova J, Tesar V, Stekrova J, Viklicky O. Influence of the endothelial nitric oxide synthase polymorphism on the progression of autosomal dominant polycystic kidney disease and IgA nephropathy. Ren Fail 2002;24(5):585-93.

26. Persu A, Stoenoiu MS, Messiaen T, Davila S, Robino C, El-Khattabi $\mathrm{O}$, et al. Modifier effect of ENOS in autosomal dominant polycystic kidney disease. Hum Mol Genet 2002;11(3):229-41.

27. Azurmendi P, Fraga A, Muchnik C, Dos Ramos Farias M, Galan F, Guerra D, et al. [Progression of autosomic dominant polycystic kidney disease. Influence of endothelial NO synthase (ecNOS) and renin angiotensin system gene polymorphisms]. Medicina (B Aires) 2004;64(2):139-42.

28. Asakimori Y, Yorioka N, Taniguchi Y, Ito T, Ogata S, Kyuden Y, Kohno N.T(-786) $>$ C polymorphism of the endothelial nitric oxide synthase geneinfluences the progression of renal disease. Nephron. 2002;91(4):747-51.

29. Nakayama M, Yasue H, Yoshimura M, Shimasaki Y, Ogawa H, Kugiyama K,Mizuno Y, Harada E, Nakamura S, Ito T, et al. T(-786)$>\mathrm{C}$ mutation in the $5^{\prime}$-flanking region of the endothelial nitric oxide synthase gene is associatedwith myocardial infarction, especially without coronary organic stenosis. AmJ Cardiol. 2000;86(6):628-34.

30. Yoshimura M, Yasue H, Nakayama M, Shimasaki Y, Ogawa H, Kugiyama K,Saito Y, Miyamoto Y, Ogawa Y, Kaneshige T, et al. Genetic risk factors forcoronary artery spasm: significance of endothelial nitric oxide synthasegene $\mathrm{T}-786->\mathrm{C}$ and missense Glu298Asp variants. J Investig Med. 2000;48(5):367-74.

31. Jeerooburkhan N, Jones LC, Bujac S, Cooper JA, Miller GJ, Vallance P,Humphries SE, Hingorani AD. Genetic and environmental determinants ofplasma nitrogen oxides and risk of ischemic heart disease. Hypertension.2001;38(5):1054-61.

Copyright: () the author(s), 2019. It is an open-access article distributed under the terms of the Creative Commons Attribution License (CC BY 4.0), which permits authors to retain ownership of the copyright for their content, and allow anyone to download, reuse, reprint, modify, distribute and/or copy the content as long as the original authors and source are cited.

How to cite this article: Annapareddy SNR, Duggirala P. To Analyze the Modifier Effect of NOS3 Gene in Hypertensive Patients of ADPKD. Acad. J Med. 2019;2(2):109-13.

DOI: dx.doi.org/10.21276/ajm.2019.2.2.27

Source of Support: Nil, Conflict of Interest: None declared. 